\title{
Performance Impairments due to Gain Transients in a Raman-based Bi-directional Long-reach PON Link.
}

Kjær, Rasmus; Tafur Monroy, Idelfonso; Jensen, Jesper Bevensee; Oxenløwe, Leif Katsuo; Jeppesen, Palle; Palsdottir, B.

\section{Published in:}

European Conference on Lasers and Electro-Optics, 2007 and the International Quantum Electronics Conference. CLEOE-IQEC 2007.

Link to article, DOI:

10.1109/CLEOE-IQEC.2007.4386469

Publication date:

2007

Document Version

Publisher's PDF, also known as Version of record

Link back to DTU Orbit

Citation (APA):

Kjær, R., Tafur Monroy, I., Jensen, J. B., Oxenløwe, L. K., Jeppesen, P., \& Palsdottir, B. (2007). Performance Impairments due to Gain Transients in a Raman-based Bi-directional Long-reach PON Link. In European Conference on Lasers and Electro-Optics, 2007 and the International Quantum Electronics Conference. CLEOE-IQEC 2007. (pp. 1-1). IEEE. https://doi.org/10.1109/CLEOE-IQEC.2007.4386469

\section{General rights}

Copyright and moral rights for the publications made accessible in the public portal are retained by the authors and/or other copyright owners and it is a condition of accessing publications that users recognise and abide by the legal requirements associated with these rights.

- Users may download and print one copy of any publication from the public portal for the purpose of private study or research.

- You may not further distribute the material or use it for any profit-making activity or commercial gain

- You may freely distribute the URL identifying the publication in the public portal 


\title{
Performance Impairments due to Gain Transients in a Raman-based Bi-directional Long-reach PON Link
}

\author{
R. Kjer ${ }^{1}$, I. Tafur Monroy ${ }^{1}$, J. Bevensee Jensen ${ }^{1}$, L. K. Oxenlowe ${ }^{1}$, P. Jeppesen ${ }^{1}$, B. Palsdottir ${ }^{2}$ \\ 1. COM•DTU, Technical University of Denmark, Ørsteds Plads $345 \mathrm{~V}, \mathrm{DK}-2800 \mathrm{Kgs}$. Lyngby, Denmark \\ 2. OFS Fitel Denmark ApS, Priorparken 680, DK-2605 Brøndby, Denmark
}

Optical amplifiers to be used in fiber-to-the-premises (FTTP) applications will need to cope with input power fluctuations due to the packet based nature of the transported data traffic and/or frequent add/drop of WDM channels. We have recently proposed and demonstrated distributed Raman amplification as a promising approach to build a bidirectional, single fiber, long-reach passive optical network (PON) link for FTTP [1]. Compared to EDFAs, Raman amplification has been found to generate smaller power peaks when used with burst-mode traffic [2]. However, the sensitivity penalties arising from transients in Raman amplified links have, to our knowledge, not been measured and published. Here, penalty measurements on a weak data channel, under the influence of two strong neighbouring channels, being periodically added and dropped in the proposed Raman-based PON link, is reported for the first time.

The link setup is described in detail in [1]. The link is $80 \mathrm{~km}$ long, based on TrueWave ${ }^{\mathbb{B} S}$ non-zero dispersion shifted fiber and pumped from both ends using four Raman pumps in total. The pump wavelengths are chosen so they provide amplification in the entire C-band. The total optical pump power is $453 \mathrm{~mW}$. A 10 Gbit/s NRZ data signal with a $2^{7}-1$ PRBS sequence is launched and detected after transmission using a simple direct detection receiver without optical pre-amplification. The signal wavelength is $1550.7 \mathrm{~nm}$. The bit-error rate (BER) is measured using a BER test set and the sensitivity is defined as the minimum received power needed to obtain a BER of $10^{-9}$. The disturbance penalty is defined as the sensitivity degradation due to the presence of the disturbing channels. Two co-propagating channels, at $1549.1 \mathrm{~nm}$ and $1552.3 \mathrm{~nm}$, are used to "disturb" the signal through cross-gain modulation (XGM). The channels are either on-off modulated at $500 \mathrm{~Hz}$, using an acousto-optic modulator, or used without modulation (CW).
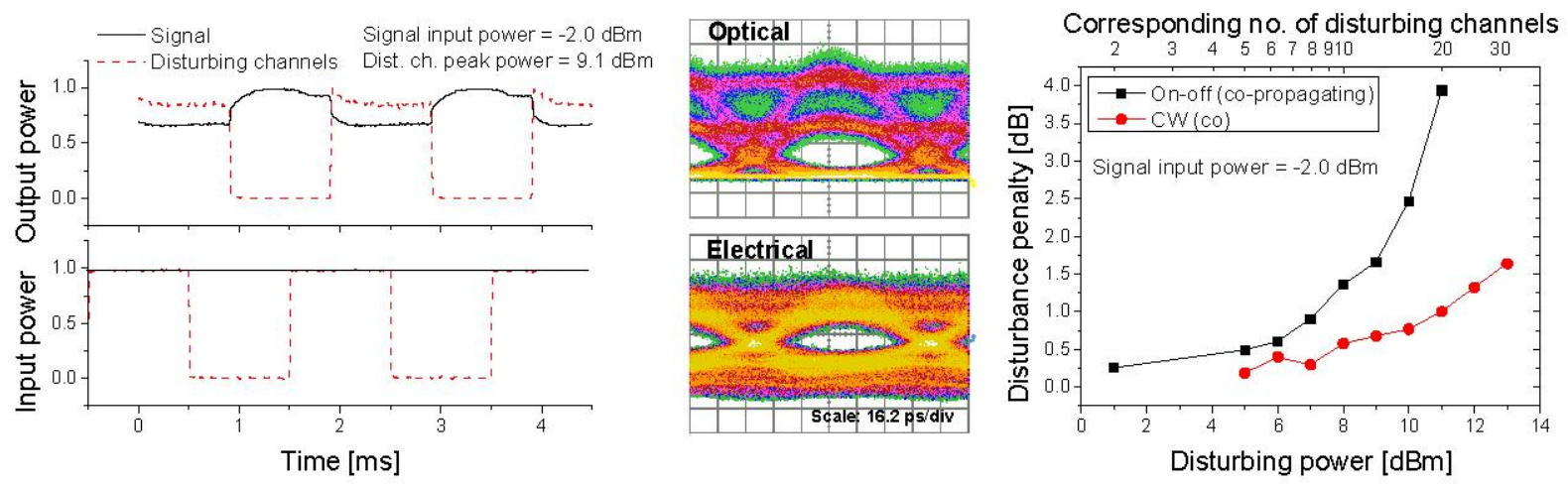

Fig. 1 Left: Normalized input and output channel transients. Middle: Optical and electrical eye diagrams of the signal after filtering. Right: Power penalty due to modulated (squares) and CW co-propagating disturbance (circles).

Fig. 1 (left) shows an example of the normalized time evolution of the slowly-varying envelope of the signal (solid) and disturbing channels (dashed) imposed by the $500 \mathrm{~Hz}$ modulation. The input signal power is $-2.0 \mathrm{dBm}$ in all the measurements and the combined peak input power of the disturbing channels is $9.1 \mathrm{dBm}$, in this case. The signal output power is seen to vary with $35 \%$ over one period, as a result of XGM from the disturbing channels. Fig. 1 (middle) shows the optical (upper) and electrical (lower) eye diagrams captured after transmission and optical band pass filtering. The one-bit level is clearly split into a saturated and an unsaturated level, in the optical diagram. In the electrical diagram, however, the one-bit levels tend to merge to a single level due to gain compression of the employed electrical amplifier. Fig. 1 (right) shows the measured power penalty vs. the co-propagating disturbance power. In case of the onoff modulated disturbing channels (squares), the power penalty stays below $1 \mathrm{~dB}$ up to a disturbance level of $7 \mathrm{dBm}$. As shown on the top axis of Fig. 1 (right), this power corresponds to an on-off modulation of 8 out of 9 channels with an input power of $-2 \mathrm{dBm} / \mathrm{ch}$. The low penalty is attributed to the high $3 \mathrm{~dB}$ saturation input power of the amplifier of 10 $\mathrm{dBm}$. The penalty is clearly lower in the CW case (circles), compared to when the channels are modulated.

In summary, the proposed link has been shown to be very robust toward WDM channel add/drops and therefore look promising for future high-capacity FTTP systems with bursty traffic.

\footnotetext{
References

1. I. Tafur Monroy et al., ECOC 2006, paper We3.P.166.

2. E. Schulze et al., ECOC 2002, paper S3.08
} 